\title{
FOUNDATIONS OF MORAL RIGHTS IN ISLAMIC SOURCES AND HISTORY OF AUTHORSHIP IN ISLAMIC CIVILISATION
}

\author{
Ezieddin EImahjub*
}

\begin{abstract}
Moral rights play an important role in modern copyright systems. They are part of the bundle of copyright authors' exclusive rights. Moral rights entitle copyright holders to claim paternity of the creative work, preserve its integrity and in some jurisdictions- to withdraw the work from the market. Copyright literature in the Arab world introduces moral rights as concepts which emerged and developed in Europe. This literature does not systematically and comprehensively refer to the existence of historical traditions on moral rights in Islamic sources and history of authorship. Yet,
\end{abstract}

Research Fellow, Queensland University of Technology. The author gratefully acknowledges the support of the Law School at Queensland University of Technology in the preparation of this paper. I am also grateful for the comments of Professor Ismail Albayrak, Dr. Nicolas Suzor, Kylie Paparando and Hope Johnson. 
concepts related to moral rights emerged in Islamic societies hundreds of years before their formation and development in Europe. Therefore, in countries with dominant Muslim populations, the protection and enforcement of moral rights should be thought of as relevant to the cultural and local context and not as a product of Western civilisation. This paper introduces evidence which shows that concepts of moral rights such as attribution and integrity are part of Islamic religious culture and traditions of authorship. This evidence is based on the main sources of the Shar' $\bar{l}$ ah and the traditions that emerged from the recording of these sources. In addition, this evidence is inferred from the development of authorship in Islamic civilisation.

Keywords: moral rights, Islamic sources, authorship, the sharı̄'ah, Islamic civilisation

\title{
ASAS-ASAS KEPADA HAK MORAL DALAM SUMBER- SUMBER ISLAM DAN SEJARAH KARYA CIPTA DALAM TAMADUN ISLAM
}

\begin{abstract}
ABSTRAK
Hak Moral memainkan peranan penting dalam sistem hak cipta modern. Ia adalah sebahagian daripada ikatan hak eksklusif pemunya hak cipta. Hak moral melayakkan pemegang hak cipta untuk menuntut paten keatas karya kreatif, memelihara integritinya dan dalam sesetengah bidangkuasa, untuk menarik balik karya dari pasaran. Hak cipta sastera di dunia Arab memperkenalkan hak moral sebagai konsep yang muncul dan berkembang di Eropah. Kesusasteraan ini tidak secara sistematik dan menyeluruh merujuk kepada kewujudan tradisi sejarah tentang hak moral dalam sumber-sumber Islam dan sejarah karya cipta. Namun begitu, konsep
\end{abstract}


yang berkaitan dengan hak moral telah muncul dalam masyarakat Islam sejak beratus-ratus tahun sebelum pembentukan dan perkembangannya di Eropah. Oleh itu, di negara-negara yang dominasi penduduknya adalah orang-orang Islam, perlindungan dan penguatkuasaan hak moral seharusnya dianggap sebagai suatu yang relevan dalam konteks budaya dan tempatan dan bukannya sebagai satu produk dari tamadun Barat. Kertas kerja ini memperkenalkan bukti-bukti yang menunjukkan bahawa konsep-konsep hak moral seperti pengiktirafan dan integriti adalah sebahagian daripada budaya agama dan tradisi Islam dalam penciptaan karya. Keterangan ini adalah berdasarkan sumber-sumber utama syari'at Islam dan juga tradisi yang muncul dari rekod-rekod yang dibuat keatas sumber-sumber ini. Di samping itu, bukti-bukti ini adalah dicerminkan daripada perkembangan karya cipta dalam Tamadun Islam.

Kata Kunci: hak moral, sumber-sumber islam, karyacipta, syari'at Islam, tamadun Islam

\section{INTRODUCTION}

Islamic sources and traditions are mainly based on the Qur'ān and the teachings of the Prophet Muhammad (pbuh) ${ }^{1}$ which are known as the Sunnah. The Qur'ān and the Sunnah create the identify and influence almost every aspect of their lives. Therefore, a discussion of any legal institution (including moral rights) from an Islamic perspective has to embark from the Qur'ān and the teachings of the Prophet (pbuh). Collectively, the Qur'ān and Sunnah are known as the Sharı̄'ah and they constitute the pillars of Islamic law and sources.

To varying degrees, the sources of the Sharî'ah affect culture and law-making in 57 countries worldwide. ${ }^{2}$ Far from being an

Peace be upon him.

2 According to the Organisation of Islamic Cooperation (OIC), Islam is the predominant religion in 57 countries around the world, OIC, "Member States", last visited Mar, 12, 2014, http://www.oic-oci. org/member_states.asp 
ancient faith system, it is an influential set of rules and philosophies, the scope of which extends beyond religious duties to regulating marriage and what to eat and wear. One of the fundamental domains of the Sharī'ah is its ability to regulate the process of law-making in Muslim societies. It operates as a normative framework for law-making in different fields of law, including intellectual property.

As a reflection of the importance of Islamic sources in societies with dominant Islamic populations, many of the constitutions of these societies refer to Islam as the religion of state and the source of legislation. These include - virtually - all the constitutions in the Arab world. ${ }^{3}$ This paper discusses the foundations of moral rights in the Islamic sources and their development in the history of authorship in Islamic civilisation.

Moral rights play an important role in modern copyright systems. They are part of the bundle of copyright authors' exclusive rights. Moral rights entitle copyright holders to claim paternity of the creative work, preserve its integrity and- in some jurisdictions- to withdraw the work from the market.

Copyright literature in the Arab world introduces moral rights as concepts which emerged and developed in Europe. This literature does not systematically and comprehensively refer to the existence of historical traditions on moral rights in Islamic sources and history of authorship. ${ }^{4}$

$3 \quad$ See for instance: "Saudi Basic Governing System (1992)", last visited Mar, 12, 2014, http://www.servat.unibe.ch/icl/sa00000 .html; art 3 of the "Yemeni Constitution (1994)", last visited Mar, 12, 2014, http://www. al-bab.com/yemen/gov/con94.htm; art 3 of the "Algerian Constitution", last visited Mar, 12, 2014 http://www.servat.unibe.ch/icl/ag00000_html art 3 of the "Moroccan Constitution (1996)", last visited Mar, 12, 2014 http://www.concourt.am/armenian/legal_resources/world_constitutions/ constit/morocco/moroco-e.htm

The Explanatory Memorandum of the Egyptian Copyright Law of 1954, which is the source of the overwhelming majority of copyright laws in the Arab World, refer to European regulation of moral rights as the source of the Egyptian regulation of them. The Memorandum does not refer to any forms of moral rights traditions in Egypt before the introduction of the European models. The Explanatory Memorandum of the old Egyptian Copyright Law of 1954 (on file with author) Furthermore, commentators on copyright in the Arab world also assume that moral rights traditions emerged 
The legal regulation of moral rights did directly emerge and develop in Europe during the 1700s and 1800s. Consequently, current scholarship dealing with copyright in the Arab world tends to assume that Islamic societies imported moral rights into their legal regimes from Europe. Yet, concepts related to moral rights emerged in Islamic societies hundreds of years before their formation and development in Europe. Evidence of this exists in the sources of the Sharì'ah, the traditions that emerged from these sources, and the development of authorship in Islamic civilisation. Contrary to institutional and scholarly opinions, concepts of moral rights are not alien to authorship in the Arab world with it predominant Islamic societies. An understanding of the position of moral rights in Islamic sources and the history of authorship in Islamic civilisations and culture has both theoretical and practical importance.

Theoretically, it will add to the comparative studies on moral rights by demonstrating their status in one of the world's largest legal systems. This study points to the existence of commonalities between Islamic legal traditions and Western philosophical and legal trends relating to notions of moral rights. Therefore, it will be of significant importance to promoting mutual understanding between Islam and other cultures, particularly in the West, concerning the regulation and management of knowledge and culture.

Practically, this paper takes into consideration that laws - including copyright laws - are sensitive to their local and cultural context. $^{5}$ This context for countries with dominant Islamic population is influenced by the Islamic sources. This paper shows that the sources of Islamic Law and the traditions of authorship in Islamic civilisation recognise concepts of moral rights. This will reveal that moral rights are part of Islamic culture. An understanding of Islamic

and developed in Europe and do not refer to the existence of concepts for protecting moral rights in the Islamic sources and history of authorship in the Islamic civilisation. See for instance Farag al-Sadda, al-Mulkiyya al-Ma nawiyya: Haq al-Muwalif (Arab Lawyers Union, 1967); Nawaf Ken`an, Haq al-Muwalif, 85 (Dar al-Thaqafa, 2004) and Nouri Hamad Kathar, Sharhu Qawa 'ed alMulkiyya al-Fikeriyyah: Haqq al-Muwalifwa-al-Huqquq al-Mujawira 203 (UAE University Press, 2008).

5 Patrick Glenn, Legal Traditions Of The World, $3^{\text {rd }}$ Ed (Oxford University Press New York, 2007). 
sources' regulation of moral rights will contribute to enforcing their legal protection. ${ }^{6}$

This paper is divided into four sections. The first section defines concepts of moral rights as they emerged and developed in modern legal systems. The second section sets context for the readers. It gives a brief introduction to the history of authorship in Islamic civilisation after the emergence and the recording of Islamic sources, namely the Qur'ān and the teachings of the Prophet. The third section explores the texts of the Qur'ān and Sunnah as well as the processes of their writings. This section will establish the existence and development of religious obligation and cultural traditions in relation to preserving moral rights. The final section gives examples that show how notions, mechanisms and principles of moral rights were regarded in Islamic history of authorship.

\section{SITUATING MORAL RIGHTS}

Legal protection and enforcement of moral rights emerged and developed in the West; namely in continental Europe. This sub-section identifies the scope of moral rights, their regulation in the international instruments and their domestic application in major jurisdictions such as civil law and common law jurisdictions.

6 In general, the introduction of intellectual property (IP) laws that are compatible with Islamic sources may assist in providing better protection and enforcement of legal rights over intellectual products. One survey included 370 students in Kuwait, $80 \%$ of them said that they would respect IP laws if it is Sharī'ah compliant while 54\% said they will respect IP if the law dictates so. Salah Al-Fadhil, The Ethical Dilemma of Software Piracy in Islamic Societies: The Case of Kuwait, 4-5, EJISDC (2009). Additionally, Heba Raslan observes that once the Azhar Fatwa (legal opinion) Committee issued a legal opinion regarding copyright in 2000, the effect on the ground 'was felt immediately' she cites the words of a Microsoft antipiracy manager in Egypt who said 'I am not going to keep it for one more minute', Heba Raslan, "Sharī'ah and the Protection of Intellectual Property the Example of Egypt” Intellectual Property L. Rev. (2007) 503. 


\section{(1) Scope of Moral Rights}

When a person creates a literary or an artistic work, the creation is considered to be an extension of the creator's personality, ${ }^{7}$ as his or her "spiritual child". ${ }^{8}$ When an author writes a book, draws a painting or composes a song, he or she integrates part of him or herself (thoughts, ideas and feelings) into the work. Modern legal systems recognise, to different degrees, the right of authors of literary and artistic works to protect the paternity and integrity of their brain child. ${ }^{9}$ Many countries around the world provide moral rights protection under their respective copyright regimes for authors to control the presentation and treatment of their literary and artistic works. ${ }^{10}$

Most known among moral rights are the right to attribution and the right to integrity. The right to attribution empowers a creator to claim paternity of the work in whatever form she likes: placing her actual name on the work, using a pseudonym or remaining anonymous. Additionally, the right of attribution entitles persons to prevent others from placing their names on works which they did not create. The right of integrity, on the other hand, empowers authors to object to any alterations, distortions, modifications or derogatory actions that may undermine their honour and reputation. ${ }^{11}$

Other two less common forms of moral right are the right to publish (droit divulgation) and the right of withdrawal (droit de retraitou de repentir). The right to publish empowers authors to

7 John Henry Merryman et. al, Law, Ethics, And The Visual Arts, $5^{\text {th }}$ ed.(Kluwer Law International, 2007) and Peter Jaszi, Toward a Theory of Copyright: The Metamorphoses of Authorship, Duke L.J,(1991), 455, 497.

8 Sam Ricketson, The Berne Convention For The Protection Of Literary And Artistic Works: 1886-1986(Centre for Commercial Law Studies, Queen Mary College: Kluwer, 1987), 456.

$9 \quad$ Article 6 bis of the Berne Convention.

10 Elizabeth Adeney, The Moral Rights Of Authors And Performers: An International And Comparative Analysis (Oxford University Press, 2006), 1.

11 Kimberly Y.W. Holst, "A Case of Bad Credit?: The United States and the Protection of Moral Rights in Intellectual Property Law", Buffalo Intellectual Property Law Journal, Vol. 3, No. 2 (2006): 108. 
control the time and conditions of publication, while the right of withdrawal empowers authors to withdraw the work from public circulation if there are valid reasons to do so (change in opinions for instance)..$^{12}$ As will be noted below, not all jurisdictions recognise these rights. ${ }^{13}$

\section{(2) International Regulation of Moral Rights}

The main international instrument that recognises and protects moral rights is the Berne Convention for the Protection of Literary and Artistic Works, 1886 by virtue of the Rome Revision in 1928. European countries such as France, Italy, Poland and Germany proposed the introduction of the moral rights regime under the Berne Convention ${ }^{14}$ and were successful in inserting a special provision (Article 6bis) to protect moral rights "independently of the author's economic rights" 15 provided under the Convention. Article 6bis states:

(1) Independently of the author's economic rights, and even after the transfer of the said rights, the author shall have the right to claim authorship of the work and to object to any distortion, mutilation or other modification of, or other derogatory action in relation to, the said work, which would be prejudicial to his honour or reputation.

(2) The rights granted to the author in accordance with the preceding paragraph shall, after his death, be

\footnotetext{
$12 \quad$ Id 109.

13 For instance, German Authors' Rights Act under $\S 13$ and Belgium Law Concerning Authors" Rights under art 12 grant the right to publish. In addition, German Authors' Rights Act under $\S 42$ recognises the right to withdraw. See Adeney, above note 10 at 1.

14 Ricketson, above note 8 at 459-460.

15 The Berne Convention for the Protection of Literary and Artistic Works, 1886, art 6bis.
} 
maintained, at least until the expiry of the economic rights. ${ }^{16}$

Article 5 regarding "Moral Rights of Performers" in the WIPO Performances and Phonograms Treaty, 1996 (WPPT) introduced the same scope of protection to performers. ${ }^{17}$ It should be noted, however, that the Berne Convention and WPPT have not recognised all forms of moral rights mentioned above and provided under copyright laws of some European countries such as France, Germany and Belgium. They only required Contracting Parties to provide protection for the right to attribution and the right to integrity and did not include the right to publish and the right to withdrawal. ${ }^{18}$

\section{(3) Domestic Application: Continental Europe and Common Law Jurisdictions}

There are interesting differences in the acceptance of moral rights between civil law jurisdictions and common law jurisdictions. Generally, civil law jurisdictions had strong traditions in protecting moral rights. ${ }^{19}$ France is considered to be the home for the development of moral rights in the Western countries. French courts are reported to have developed traditions which accorded protection to moral rights ${ }^{20}$ based on principles that occurred in France during the Renaissance ${ }^{21}$ and on the revolutionary decrees issued in 1791 and 1793. ${ }^{22}$ Additionally, in Germany, and partially

16 The Berne Convention for the Protection of Literary and Artistic Works, 1886, art 6bis.

17 WIPO Performances and Phonograms Treaty, 1996, Article 5.

18 Ricketson, above note 8 at 467.

19 Merryman, above note 7.

$20 \quad$ Ricketson, above note 8 at 457

$21 \quad$ Harold C. Streibich, "the Moral Right of Ownership to Intellectual Property: Part I - From the Beginning to the Age of Printing", Mem. St. U. L. Rev. 1, 5, 23 (1975): 6.

22 These two decrees date back to the French revolution. First Decree was issued on 13-19 January 1791 and "established the prerogative of authors to authorize or prohibit public performance of their compositions". The other degree was issued on July 19 and 6 August 1793 and "gave to authors exclusive rights over the publication of their works". However, first comprehensive statutory 
as a result of the ideas of Immanuel Kant on personal rights, ${ }^{23}$ a more comprehensive legal regime for moral rights was developed in 1870 and $1876 .{ }^{24}$ Germany's comprehensive approach to moral rights influenced the French "to formulate the theoretical basis of their laws." 25

By the 1920s, other civil law jurisdictions extended protection to moral rights; particularly, the right to attribution, the right to integrity and the right to publish. In the Rome Conference of 1928, France, Italy, Poland and Germany were the leading advocates for the inclusion of moral rights in the Berne Convention. They were successful despite strong opposition from common law jurisdictions. ${ }^{26}$

Common law countries have been slow in recognising moral rights in their legal system. Traditional common law countries such as United Kingdom and Australia, while members to the Berne

protection for moral right was not introduced until 11 March 1957 with the enactment of French Law on Literary and Artistic Property. Raymond Sarraute, 'Current Theory on the Moral Rights of Authors and Artists under French Law', Am. J. Comp. L. 16465, (1968) 465-466.

It is argued that the development of moral rights in Germany and partially in Europe is attributed to Kant's ideas on the rights of personality. It is reported that Kant in 1785 had contributed to the then-ongoing public debate on the legitimacy of the reproduction of literary works. Kant argued in favour of protection against unauthorised reproduction based on the personal characteristics of authorship. Kant argued that author's rights is considered "an inherent right in his own person, namely a right to prevent another making him address the public without his consent" Adeney, above note 10 at 2526.

24 L. Bently \& M. Kretschmer, Copyright Act for the German Empire, Berlin (1870) Primary Sources on Copyright (1450-1900), MaxPlanck-Institut für Europäische Rechtsgeschichte, Frankfurt, Mar, 12, 2014, http://copy.law.cam.ac.uk/cam/tools/request/showRecord php?id=record d 1870

$25 \quad$ Ricketson, above note 8 at 458 .

26 Ricketson, above note 8 at 459-46. The proposals that were presented to the Rome Conference by number of civil law jurisdictions met objection by common law countries on the basis that moral rights are already protected under other heads of legal liability such as defamation. The resistance of common law countries for the protection of moral rights continued and became even stronger in Stockholm Revision in 1967. Ricketson, above 8 at 466. 
Convention, opposed international recognition for moral rights at both the Rome Conference and later the Stockholm Revision in 1967. It took the United States more than one century to accede to the Berne Convention. ${ }^{27}$ Even after accession, Congress did not introduce special provisions on moral rights. On the contrary, congress claimed that miscellaneous provisions in the United States laws provide adequate protection for moral rights. ${ }^{28}$ However, the United States, as is the case with other common law jurisdictions ${ }^{29}$ (with the exception of Australia), ${ }^{30}$ does not seem to adequately meet the international standards on moral right as articulated under art 6 bis of the Berne Convention. ${ }^{31}$

27 Berne Implementation Act, 1988, Pub.L. No. 100-568, 102 Stat. 2853 $\S 3$ (b) (1988).

According to the House of Representatives various legal mechanisms under American law provide protection for moral rights. It stated that: There is a composite of laws in this country that provides the kind of protection envisioned by Article 6bis. Federal laws include 17 U.S.C. $\S 106$, relating to derivative works; 17 U.S.C. $§ 115(\mathrm{a})(2)$, relating to distortions of musical works used under the compulsory license respecting sound recording; 17 U.S.C $\$ 203$, relating to termination of transfers and licenses; and section 43(a) of the Lanham Act, relating to false designations of origin and false descriptions. State and local laws include those relating to publicity, contractual violations, fraud and misrepresentation, unfair competition, defamation, and invasion of privacy. In addition, eight states have recently enacted specific statutes protecting the right of integrity and paternity in certain works of art. Finally, some courts have recognized the equivalent of such rights. Natalie C. Suhl, Moral Rights Protection in the United States Under the Berne Convention: A Fictional Work?, 12 Fordham Intell. Prop. Media \&Ent. L.J.1203, 1206-08 (2002)1213 ( quoting H.R. REP. No. 609, 100th Cong., 2d Sess 32-34 (1988)) With regard to United Kingdom see Lionel Bently and Brad Sherman, Intellectual Property Law, $3^{\text {rd }}$ ed, (Oxford University Press, 2009), 253-260.

$30 \quad$ Copyright Amendment (Moral Rights) Act 2000 (an Act to amend the Copyright Act 1968). Under this amendment a comprehensive regulation for moral rights were introduced under Australian Copyright Law, 1968. See sections 189 to section 195AZR.

$31 \quad$ Gerald Dworkin, "The Moral Right of the Author: Moral Rights and the Common Law Countries", Colum.-Vla J.L. \& Arts, 229 (1995):19. Mark A. Lemley, "The Economics of Improvement in 
Essentially, two reasons are introduced to explain the reluctance of common law jurisdictions to implement moral rights within their copyright regimes. First is that moral rights rhetoric does not respond to "the strong economic orientation of the common law systems". ${ }^{32}$ The second reason is related to the importance that civil law countries, particularly France, Italy and Germany, placed on the development of arts as expression of the personality, while common law countries are characterised with strong emphasis on industry rather than arts. ${ }^{33}$ At this stage, the position of moral rights in Islamic culture and civilisation will be discussed.

\section{FLOURISHING OF AUTHORSHIP IN ISLAMIC CIVILISATION}

The emergence of Islamic sources, particularly the Qur'ān and the teachings of the Prophet, contributed to significant developments in relation to authorship even outside religious knowledge. This section briefly demonstrates that in its early days, Islamic civilisation enjoyed strong traditions based on producing literary works. As a result, authorship across diverse fields of knowledge existed at large scales and literary works were consistently developed. Concepts of moral right such attribution and integrity flourished within this environment.

Before the emergence of Islam, the Arabs were very famous for composing poetry. Fine poems were written and put on the walls of Mecca. ${ }^{34}$ However, apart from poetry, there are no historical records which indicate that written authorship existed in the Arab world before transcribing the Qur'ān as a book in the second half of the seventh century. Accordingly, the history of Islamic knowledge and science in general, and therefore authorship specifically has only been recorded after the revelation of the Qur'ān and the emergence of teachings of the Prophet.

\footnotetext{
Intellectual Property Law" 75 Tex. L. Rev. 989, (1996-1997):1035. Ricketson, above note 8 at 459 Merryman, above note 7 at 232. Ahmed al-Shanqiti, al-Mu'alaqat al-'shrwa Akhbar Shu'ara'iha, (Dar Al-Nasr, 2008).
} 
The compilation of the Qur'ān and the Sunnah paved the way as a being a vital source of knowledge and understanding. In the first instance, these sources were the bases of pure religious knowledge such as interpretations of the Qur'ān and Sunnah and Islamic jurisprudence and indirectly contributed to promoting non-religious knowledge. ${ }^{35}$ Therefore, it is conceivable to argue that concepts of moral rights which derived from the Qur'ān and Sunnah influenced the development of authorship in the Islamic world.

One of the historical landmarks in the development of authorship in Islamic civilisation occurred in $950 \mathrm{CE}$ as a result of the establishment of the first factory to produce papers in Baghdad, the capital of Abbasid Caliphate. ${ }^{36}$ After that, paper production flourished with the establishment of other factories in other cities within the Islamic states such as Cairo, Granada, Toledo and Cordoba. ${ }^{37}$ The flourishing of paper production has significantly contributed to raising the levels of authorship and books production. ${ }^{38}$ An independent profession known as warraq (book seller/ publisher) existed in various cities in the Islamic states to buy books from authors and resell them to the public. ${ }^{39}$

Furthermore, authorship in Islamic civilisation flourished within the institutional framework as a result of establishing specialised centres for learning and teaching known as maktabat

35 TahaBaqqer, Mūjaz fi Tarikh al- 'ulumwa al-Ma 'arif, 156 (al-Dar alDawliyya li al-Estithmarat al-thaqafIyya, 2002). Muslims believe that the first verse revealed to the Prophet is iqra (read). This believe created a widespread assumption in the Islamic world that Muslims are a nation of science and knowledge and therefore of authorship. EssamAbd al-Raūf, Tarikh al-Fikr al-Islami, 189 (Dar Al-Fikr alArabi, 1997).

37 HamedDiyab, al-Kutubwa al-Maktabat fi al-Andalus, 31 (Dar Qeba, 1998).

$38 \quad$ Diyab, above note 37 at 31.

39 Abd al-Raūf, above note 36 at 189; Diyab, abovenote 37at 60, 67, 70 and 102. A city like Baghdad was known as Madinatu al-Waraqūn (city of book sellers). It has been narrated by Ahmad ibn Abi Ya'qub that in $891 \mathrm{CE}$, there were more than 100 book sellers in Baghdad. Hans H. Wellisch, The First Arab Bibliography: Fihrist al-'Ulum, 6 (Volume 175 of Occasional Papers / University of Illinois Graduate school of library and information science, ISSN 0276-1769, 1986). 
(libraries). ${ }^{40}$ What is unique about maktabat is that the Islamic state since the 800s CE recognised the intellectual creations of its residents and through these institutions allocated budgets to compensate them for writing books. Three examples of famous libraries in Islamic civilisation will now be provided with reference to their approach to authorship.

The first example is Bayt al-Hikma (House of Wisdom). This library was founded in Baghdad during the Abbasid Caliphate (7501517 CE) under the rule of Caliph Abu Jafar al-Mansour (714 - 775 $\mathrm{CE}),{ }^{41}$ and it significantly expanded under the rule of Caliph al-Mamun ibn Haroun al-Rashid (813-833 CE) ${ }^{42}$

The main purpose for establishing Bayt al-Hikma was to promote scientific authorship and discoveries and to translate the scientific books from other civilisations such as Greek, Persian and Indian civilisations. ${ }^{43}$ Bayt al-Hikma contained approximately 200,000 books.

Bayt al-Hikma was divided into different sections, ${ }^{44}$ which included: Firstly, qism al-naskh (reproduction section), which was tasked with making copies of the books. ${ }^{45}$ Secondly, qism al-tarjama (translation section) which was specialised in translating books from different languages into Arabic. Finally, there was qism al-ta'lif (authorship section) in which authors would write books to be placed in Bayt al-Hikma in exchange for money. ${ }^{46}$

It has been reported that the books of Plato, Aristotle, Hippocrates and Galen were first translated into Arabic in Bayt al-

$40 \quad$ Roldah Adams, Historical Development of Islamic Libraries Internationally and in South Africa: A Case Study of the Islamic Library in Gatesville (Master dissertation, Department of Library and Information Science, University of the Western Cape, 2003), 6.

$41 \quad$ Saiyyid de Yüji, Bayt al-Hikma (MaktabatKounouzAl-ilm, 2006), 33.

42 Yüji, above note 41 at 35, see also Amira K. Bennison, The Great Caliphs: The Golden Age of the Abbasid Empire (Yale University Press, 2009), 179.

$43 \quad \mathrm{Yu} \mathrm{j} \mathrm{i}$, above note 41 at 35 and Abd al-Raūf, above note 36 at 199.

Abd-Albasit A. al-Alūssī and Uthmān. A. al-Muhammadi, "Minrawa'i ' al-Hadara al-Islamiyya: Bayt al-Hikmanumudhajjan", Journal of Diyalla, (2009) and Abd al-Raūf, above note 36 at 194.

$45 \quad$ Abd al-Raūf, above note 36.

46 Abd-Albasit A. al-Alūsssī and Uthmān .A. al-Muhammadi, above note 44 . 
Hikma. Scholars of Bayt al-Hikma were reported to be keen to verify the attribution and the integrity of the original texts. For instance, some of them used to call Aristotle as al-mua' lim al-awal (the top master) in recognition for his scholarship and contributions in philosophy. ${ }^{47}$

The second example is the Dar al-'ilm (House of Knowledge), which was founded during the ruling period of the Fatimid ${ }^{48}$ Caliph al-Hakim-bi-Amre-Allah (996-1021 CE). Dar al-ilm functioned as a place to promote knowledge and creativity and was the largest knowledge centre in the world with 600.000 books in its shelves. ${ }^{49}$

The third example is the Library of Cordoba which was established under the rule of Caliph al-Hakam ibn Abdu al-Rahman (961-976 CE). The Library of Cordoba contained over 400,000 books in different languages such as Arabic, Latin, Persian and Indian. As is the case with Bayt al-Hikma, the Library of Cordoba was divided into different sections such as: reproduction section, translation section and authorship section. Scientists across the religious spectrum worked in the Library and produced vast amount of knowledge that benefited humanity until the modern day in various fields such as medicine, philosophy, engineering, mathematics and astronomy. ${ }^{50}$

To sum up, after the emergence and the transcribing of the Qur'ān and Sunnah, authorship flourished in the Islamic civilisation. Islamic regions featured a fertile environment to the emergence of sustainable and large scale authorship. There were traditions and mechanisms governing the preservation and development of this fertile environment for authorship and literary production. The next section introduces some of these traditions and mechanisms in relation to the protection of moral rights.

\footnotetext{
$47 \quad$ Yīji, above note 41 at 20.

48 The Fatimid Caliphate ruled various areas in Muslim world such Egypt, the Maghreb, Sudan, Sicily, the Levant, and Hejaz from 909 $\mathrm{CE}$ to $1171 \mathrm{CE}$.

$49 \quad \mathrm{Y} \bar{u} \mathrm{ji}$, above note 41 at 44.

50 Diyab, above note 37 at 111-120.
} 


\section{ROOTS OF MORAL RIGHTS IN THE ISLAMIC SOURCES AND TRADITIONS}

Support for notions of moral rights in Islamic sources and traditions can be established in various ways. On one side, the texts of the Qur'ān and the Sunnah recognise the importance of attribution and integrity in relation to religious texts. They can also be interpreted to condemn acts that amount to transgressing on moral rights as being dishonest acts prohibited by Islam. On the other side, the traditions which evolved and developed around recording and preserving the Qur'ān and Sunnah reveal notions of moral rights, which later extended to knowledge outside the religious texts.

Islamic sources and traditions do not condone manipulations of the divine texts. ${ }^{51}$ The trend in the main sources shows that the integrity and attribution of the religious texts should be carefully safeguarded and preserved. For instance, the Qur'ān warns against any manipulation and false attribution of the Qur'ānic text:

And indeed, there is among them a party who alter the Scripture with their tongues so you may think it is from the Scripture, but it is not from the Scripture. And they say, "This is from Allah," but it is not from Allah. And they speak untruth about Allah while they know. ${ }^{52}$

Moreover, verses in the Qur'ān that mandate honesty and prohibit deceitful practices provides additional support for preserving moral rights, and particularly the right to attribution and integrity. The Qur'ān says "Indeed, Allah commands you to render trusts to whom they are due"53 and "O you who have believed do not betray Allah and the Messenger or betray your trusts while you know [the consequence"]." 54 Infringing moral rights by transgressing on the author's rights to the paternity of her /his work or by modifying the work against her/his will may be considered as deceitful practices which fall within the scope of the mentioned Qur'ānic texts. ${ }^{55}$

$51 \quad$ Ali Khan, "Islam as Intellectual Property: My Lord! Increase me in knowledge”, Cumberland L. Rev., Vol. 31, (2001):361.

52 The Qur'ān (Sahih International trans.) 3:78

53 Qur'ān (Sahih International trans.) 4:58.

$54 \quad$ The Qur'ān (Sahih International trans.) 8:27.

55 For similar opinion regarding intellectual property rights in general see 
Indeed, some Muslim authors invoked these verses to establish a religious obligation against infringing the right to attribution and integrity six hundred years ago as discussed below.

The same thing could be noticed from the Sunnah of the Prophet (pbuh). The Prophet warns against both, using his name to mislead people and taking advantage of them (people), in the name of religion. The Prophet is reported to have said that "he who attributed any falsehood to me ... deliberately... he should in fact find his abode in the Hell-Fire" "56 As is the case in the Qur'ān, the Prophet also warns against cheating "...he who cheats us, is not one of us" ${ }^{57}$ In particular, cheating that leads to misleading people or creating a false impression about ownership of an object. In this regard, the Prophet says "the one who creates a false impression of receiving what one has not been given is like one who wears two garments of falsehood". ${ }^{58}$

The knowledge contained in Islam was transmitted generations after generations by way of narration. Both, the Qur'ān and Sunnah were carefully preserved. The collection and tabulation of all Qur'ānic parchments written in the prophet's presence involved enormous efforts that were undertaken during the time of the third Caliph Uthmān ibn Affan (d. 656CE)

Ibn Sirin (d. 733 CE) reports that Uthmān ibn Affan appointed a committee of twelve companions to verify the Qur'ānic texts and to ensure that what will be transmitted in the new musahă $f$

Amir H Khory, "Ancient and Islamic Sources of Intellectual Property Protection in the Middle East: A focus on Trademarks", 43 Idea: The Journal Of L. And Tech., (2003):173.and Nasser M Alghamidi, Protection of Intellectual Property in Islamic Jurisprudence and its Economic Implications (Mar, 3, 2012) http://hawassdroit.ibda3.org/ t712-page

Translation of Sahih Muslim Hadìth no 118, available online at: http://muttaqun.com/files/PDF/Sahih-Muslim.pdf, also in Sahih al-Bukhari, Vol 4, book 56, no 667, available online at: http:// d1.islamhouse.com/data/en/ih_books/single/en_Sahih_Al-Bukhari. pdf

57 Ibn Jarir Al-Tabari, al-Mu jjamal-Kabir, 169 (Hamdi Al-Salafu. Ed., MaktabiatIbnTayymia).

58 See Sahih Al-Bukhari, 7/146 http://muttaqun.com/files/PDF/sahihbukhari.pdf 
(the Compilation of Qur'ān) is the text which was revealed to the Prophet (pbuh). ${ }^{59}$

With regard to Sunnah, since the commencement of the systematic recording of its texts in late 700s CE and early 800s CE, strong traditions emerged to preserve its attribution and integrity. AlSayyid al-Ghanuji (d. 1889 CE) ${ }^{60}$ illustrates how scholars of Hadith (Prophet's traditions), such as Malik, ${ }^{61}$ al-Bukhari ${ }^{62}$ and Muslim, ${ }^{63}$ collected the traditions of the Prophet. These scholars were eager to ensure that the transmitted Hadith were properly attributed and that their integrity were preserved. Both Imams Al-Bukhari (d. $807 \mathrm{CE}$ ) and Muslim (d.875 CE) selected over 7,000 Hadith out of 300,000 sayings which were attributed to the Prophet (pbuh). ${ }^{64}$ The collected Hadith are believed to be authentic in terms of their integrity and attribution. ${ }^{65}$

For instance, Imam Muslim, one of the main authorities in recording, narrating and preserving the traditions of the Prophet (pbuh) in one book, allocates the introduction (al-Muqadima) of his famous book 'Sahih Muslim'to stress the significance of preserving the attribution and integrity of hadith to the Prophet (pbuh). He entitles his very first chapter "The Obligation Of Narrating From The Trustworthy And Ignoring The Liars; And The Warning Against Telling Lies About The Messenger Of Allah" 66 and entitles the second chapter "The Seriousness Of Telling Lies About The Messenger of Allah". ${ }^{67}$

A completely discrete science was developed to protect the authenticity of the transmission of the Prophet's sayings (hadiths),

$59 \quad$ For more on this see Muhammad Mustafa Al-A'zami, The History of The Qur'annic Text From Revelation To Compilation: A Comparative Study With The Old And New Testaments (UK Islamic Academy, 2003),89. Al-Sayyid Seddeq Hassan Khan, al-Hittafi Dhikral-Sihahal-Sitta, Edited By Ali Hassan al-Halabī, (Dar Al-Jalil, Beirut and Dar Ammar, Amman No date of publication). Al-Sayyid, above note 60 at 275 .

Al-Sayyid, above note 60 at 295 .

Al-Sayyid, above note 60 at 352 .

See Hafiz Abu Tahir, English Translation of Sahih Muslim (Darussalam 2007)35.

$65 \quad$ Al-Sayyid, above note 60 at 295.

66 Abu Tahir, above note 64 at 43.

67 Abu Tahir, above note 64 at 45 . 
that is, 'ilmal-Jarhwa al-Ta'dì $l$ (science of hadìth authenticity).$^{68}$ The main objective of 'ilmal-Jarhwa al-Ta'dìl is to ensure that a certain text (matn) is not falsely attributed to the Prophet (pbuh) and that the text is not distorted or modified. Sunnah scholars developed, through 'ilmal-Jarhwa al-Ta' dìl, a mechanism known as isnad (chain of narrators) to ensure the integrity and attribution of any transmitted texts. ${ }^{69}$ Isnad refers to a list of individuals who report a particular saying or action of the Prophet (pbuh). The classic books of hadith starting with the most famous one (Sahih al-Bukhari) demonstrates isnad in the following form: it has been narrated to me (hadathana) by A on the authority of B on the authority of $\mathrm{C}$ on the authority of $\mathrm{D}$ that the Prophet (pbuh) said. ${ }^{70}$

The concept of isnad is central in verifying the attribution and integrity of the Prophet's sayings. Muhammad al-Sakhawi (d. $1497 \mathrm{CE}$ ) states that verifying the chain of narrators (isnad) is a prerequisite for the validity and acceptance of hadith. He quotes many classic Muslim scholars who emphasise the importance of isnad in Islamic literature, particularly in relation to ensuring the attribution and integrity of the sayings of the Prophet (pbuh). ${ }^{71}$ The following discussion will highlight how the concept of isnad affected the Islamic literature as well.

$68 \quad$ This science is considered one of Sunnah sciences and it is mainly concerned with the studying of the chain of narrators from the Prophet (pbuh) to preserve the knowledge of the Prophet and avoid any false attribution to him. The history of this science dates back to the era of the companions, which started after the demise of the Prophet in (632 C.E) and continued to evolve throughout the stages of Islamic Figh. On the history of the science of al-Jarhwaal-Ta'dīl, see Adnan Ahmed Atef, 'ilmal-Jarhwa al-Ta 'dīl: ahamiyyatuhu, wa Tarekha'hu, wa Qawaidahu, 2, Majalat Markaz Buhutal-Sunnahwaal-Sirra, Qatar University, 422 (1987). And for detailed account on the rules of this science see Ibnal-Mulaqin, al-Mughnī fi 'ulum al-Hadīi (Dar Fawazli al-Nasher, 1992).

$69 \quad$ For additional information, please see Atef, above note 68 at 422 . And for detailed account on the rules of this science see Ibn alMulaqin, above note 68.

70 See for example Muhammed Khan, Translation of Meanings of Sahih Al-Bukhari (Darussalam, 1997).

71 Muhammed al-Sakhawi, Fat'hu al-Mughit Bisharh Alfyat al-Hadìth (Maktabat Al-Sunnah, 2003), 330-331. 
There is a massive body of Islamic classic scholarship - let alone the modern scholarship - that deals, in various forms, with the study of attribution and integrity of the Sunnah in general. For instance, two leading Muslim scholars in Sunnah sciences, Imam al-Dhahabi (d. $1348 \mathrm{CE}$ ) and Imam al-Suyuti (d. $1505 \mathrm{CE}$ ), in their books Tadhkiratual-Hufaz maintain that since the death of the Prophet (pbuh) there were over 1100 individuals who contributed in various ways to preserve the attribution and integrity of the traditions of the Prophet. Among those individuals, there are a great many classic scholars who worked, for hundreds of years, to establish systems and rules for preserving the attribution and integrity of the traditions of the Prophet (pbuh). These systems involved researching the best possible methods of documenting the texts of Sunnah, criticising the chains of narrators (isnad) and verifying the texts of Sunnah to determine that these texts are properly attributed to the Prophet and that their integrity is doubtless. Examples of those leading scholars include al-Khatib alBaghdadi (d. $1071 \mathrm{CE}),{ }^{72} \mathrm{Ibn}$ al-Salah (d. $\left.1245 \mathrm{CE}\right),{ }^{73}$ Imam al-Nawawi (d.1278 CE) ${ }^{74}$ Ibn Taymiyyah (d.1328 CE $)^{75}$ and Ibn Hijral-' asqalani (d. $1448 \mathrm{CE}){ }^{76}$

In summary, the Islamic source and the traditions which evolved around preserving these sources support notions of moral rights, particularly, the right to attribution and integrity. Ali Khan has

72 Al-Dhahabi reports that al-Baghdadi authored 56 books in total. Those related to preserving the Sunnah include: al-Kifaya fi ma'rifatusul 'ilm al-riwaya; Takyid al-'ilm; al-Rihla fi talab al-Hadìth. Shamsualdīn Al-Dhahabi, Tadkiratual-Hufaz, (Dar al-Kutubal-'Ilmiyya No date of publication) 1138 .

73 Ibn al-Salah's most relevant books to preserving the Sunnah include: Muqaddimah Ibn al-Salāh and Siyanah Sahih Muslim. For more on his contributions see Al-Dhahabi, above note 72 at1430.

74 See Jalal al-Dīnal-Suyuti, Tadhkiratu Al-hufadh, 513 (Dar Al-Kutub Al-Ilmiyya).

$75 \quad$ Al-Suyuti, above note 74 at 520.

76 Ibn Hijr is considered by al-Suyuti to be the leading scholar in Sunnah sciences. He authored over 150 books during his life time. Those which related to preserving the Sunnah include: al-Isaba fi tamyiz al-Sahaba; Tahdhib al-Tahdhib; Nata'ij al-Afkar fi Takhrij AHadīth al-Adhkar; al-Diraya fi TakhrijAhadith al-Hidaya and Ta rifAhl alTaqdis bi Maratib al-Mawsufin bi al-Tadlis. For more on IbnHijr see al-Suyuti, above note 74 at 552-53. 
described the "protected knowledge of Islam as a form of intellectual property. The Qur'ān, the Sunnah and the unique marks and symbols of faith, together constitute the protected knowledge of Islam" ${ }^{77}$ the owner of which is God almighty. Concepts of moral rights which developed in religious texts extended to authorship outside the religious knowledge.

\section{MANIFESTATIONS OF PRIMITIVE FORMS OF MORAL RIGHTS IN THE HISTORY OF ISLAMIC AUTHORSHIP}

The Qur'ān and the teachings of the Prophet in relation to preserving attribution and integrity influenced authorship in fields outside religious knowledge and Islamic jurisprudence. This occurred because of the following:

Firstly, sustainable authorship has only emerged in the Islamic world after transcrining the Qur'ān and the Sunnah. Therefore, the ethical values underpinning the texts of the Qur'ān and Sunnah, which prohibit misleading and cheating in general, constituted grounds for Muslim scholars to condemn infringing an author's rights to attribution and integrity. This is evident from examples discussed below.

Secondly, the traditions which emerged around writing and preserving the attribution and integrity of the Islamic sources, particularly the Sunnah, found its way to non-religious knowledge such as literature and history.

Thirdly, authors of books outside the religious knowledge used to explicitly reveal their identities as believers in Islam at the introduction of their books. Furthermore, some jurists of Islamic jurisprudence used to compose books outside the scope of religious knowledge. Examples of those jurists include al-Suyuti and al-Jawazi who composed books related to preserving attribution and integrity in literature. The principles contained in Islamic sources, as well as the traditions which were developed in relation to preserving the attribution and integrity of the Qur'ān and Sunnah, contributed into shaping traditions of attribution and integrity in non-religious authorship. Support for this appears in the following sections.

Attribution and integrity, the main component of moral rights, were essential aspects in the development of literary production in Islamic civilisation, particularly in relation to poetry and books. This

$77 \quad$ Ali Khan, above note 51 at 631. 
next section identifies examples of Islamic traditions that preserve attribution and integrity and shows how Islamic sources contributed to the development of these traditions.

\section{(1) Moral Rights in Poetry}

Since the pre-Islamic period which is known as Jahiliyy $a^{78}$ original authorship in literary works, specifically, poetry was highly regarded. ${ }^{79}$ The emergence of a professional poet in a tribe was a matter of supreme importance. Poets played the role of media in that era as the words of a poet were considered to be an effective method ${ }^{80}$ of encouraging the men in a tribe to defend against or attack other tribes. Additionally, poems played a role as a repository for recording the major events in a certain tribe. ${ }^{81}$

With the advent of Islam, poetry remained a matter of great social importance, as a consequence, the Qur'ān addressed it in a separate sura (chapter) titled "the Poets" 82 in recognition of its influence in the various affairs of the society. In this sura, the Qur'ān classifies the types of poetry which are compliant with its teachings and those which are not.

If a poet creates a poem his or her work will be transmitted to the public by recitation. Each time the poem is recited, the person reciting it must include the full name of the poet, and by putting his or her name over the poem a poet could claim ownership on it. ${ }^{83}$ With the expansion of the Islamic states beyond the Arabian Peninsula to other cultural centres such as, Damascus, Baghdad, Cairo, Qayrawan, Fez and

78 Jahiliyya means ignorance and it refers to the condition in which the Arabs lived prior to the revelation of the Qur'ān.

79 Basic forms of trademarks of intellectual property were recognised in the pre-Islamic and post Islamic period; however such forms have not gone through sustainable development as the case with original authorship. Khory, above note 55 at 155. Allen Roger, Introduction to Arabic Literature (Cambridge University Press, 2000), 109.

81 Roger, above note 80 at65. The Arabs describe their poem as (diwan al-arab), namely; repository of Arabs

82 The Qur'ān: Chapter 26.

$83 \quad$ Khory, above note 55 at 155. 
Cordoba, the importance of poetry increased ${ }^{84}$ Fine poets guaranteed a place in the courts of Caliphs and the other rulers of Islamic regions and were paid for the poetry they produced. ${ }^{85}$

Due to the high status that poets enjoyed, some individuals tried to free ride by forging or copying others' poems and attributing those forged poems to themselves. These practices were strictly monitored and harshly condemned. ${ }^{86}$ The punishment was casting its doer away from the cultural society, which is considered to be among the most severe punishments. ${ }^{87}$ Ibn Salam (d, $\left.846 \mathrm{CE}\right)$ in his highly acclaimed treaty Tabakat Fuhul Ashu'ara (Classifications of Prominent Poets) referred to claims and counterclaims on poem thefts from the pre Islamic period till his death. ${ }^{88}$

Muḥammad Ibn Hasanal-Nawaji (d. 1455 AD) composed a book titled Kitāb al-Hujjah fì sariqāt Ibn Hijjah (The Proof in the Infringements of ibn Hijjah) to demonstrate the significance of infringing poetry in Islamic traditions. ${ }^{89}$

At the introduction of his book, al-Nawaji quoted a verse from the Qur'ān which says "Indeed, Allah commands you to render trusts to whom they are due"..$^{90}$ This verse is used to establish a religious obligation on authors to properly attribute knowledge and information to their rightful creator or composer. ${ }^{91}$

Al-Nawaji proceeded to claim that Ibn Hijjah (Muslim poet $d$. $1433 \mathrm{AD}$ ) was not an original author and that he infringes the poems

$84 \quad$ Patrick S. O’Donnell, Poetry and Islam: An Introduction, Volume 61, Issue 1, (Cross Currents, 2011), 72, 73.

$85 \quad$ Khory, above note 55 at 155

86 Silvia Beltramitti, "The Legality of Intellectual Property Rights Under Islamic Law”, 56 Prague Yearbook of Comparative Law (2009).

$87 \quad$ Khory, above note 55 at 155.

88 Ibn Salam al-Jamahi, Tabakat Fuhul Ashu'ara (Umm Al-Qura University, no date of publication).

89 A manuscript of the book is available at Harvard Library: Muhammad ibn Hasan Al-Nawājī, Kitāb al-Hujjahfīsariqāt ibn Hijjah (manuscript, undated. MS Arab 285) Mar, 12, 2014, http://pds.lib.harvard.edu/pds/ view $/ 12139575 ? \mathrm{n}=6$ \&imagesize $=1200 \& \mathrm{kj} 2 \mathrm{Res}=.25 \&$ print Thumbna $\underline{\text { ils }=\text { no }}$

90 The Qur'ān (Sahih International) 4:58.

$91 \quad$ Al-Nawājō, above note 89 at 6. 
of other poets and attributes them to himself. ${ }^{92}$ In proving his claim, Al-Nawaji quotes tens of poems and identifies their rightful authors and after that quotes Ibn Hijjah's poems and discusses how ibn Hijjah infringed the original poems. ${ }^{93}$

\section{(2) Moral Rights in Books}

Notwithstanding that the concept of isnad (chain of narrators) was developed to authenticate the attribution and integrity of the texts (matn) of Sunnah, it also influenced authorship in other fields of knowledge. Ibn Khaldun (d. 1406 CE) reports that it was a common practice in the movement of authorship in Islamic civilisation for authors to identify previous authors and narrators from which they have obtained the content of their books. ${ }^{94}$ For instance, it is reported that Imam Sufyan al-Thawri (d.778 CE), one of the leading scholars of the Sharī'ah, warned against false attribution of knowledge and considered the proper attribution of knowledge to its creator as an essential aspect of honest authorship. ${ }^{95}$ Similarly, Imam al-Nawawi (d. $1278 \mathrm{CE}$ ) strongly advised scholars to carefully attribute knowledge to its creators and maintained that the proper attribution will bring blessings to the knowledge of those who are eager to attribute it to the rightful author. He also advised to abandon authors who infringe the right to attribution of others as a punishment. ${ }^{96}$

Moreover, books outside the field of religious knowledge and Islamic jurisprudence paid considerable attention to isnad. For example, books related to literature, history and cultural traditions such as al-Basa'irwa al-Dhakha'ir written by philosopher Abu Haiyyan alTawhidi (d. 1023 AD) ${ }^{97}$ al-Iqd al-Farid written by Moorish thinker Ibn

\footnotetext{
$92 \quad$ Al-Nawājīi, above note 89 at 21.

93 Al-Nawājīi, above note 89 at 23.

$94 \quad$ Ibn Khaldun, al-Muqadima, Vol 2, 322 (Bayt al-'ulum wa al-Fununwa al-Adab, 2005). For more see Diyab, above note 37 at 73. Al-Hattab al-Ruwaini, Mawahib al-Jalil (Zakaria Umirat ed. Dar alKutub Al-'ilmeyia, 1995), 8.

Shamsu al-Din al-Nawawi, Bustan al-A'rifin (Muhammed Al-Hajjar ed. Dar al-Bashayir al-Islamiyya, $6^{\text {th }}$ ed 2006) 47 .

97 Abu Haiyyan al-Tawhidi, al-Basa'irwa al-Dhakha'ir, Islamic Books (Mar, 12, 2014) http://www.islamicbook.ws/adab/albsaer-
} 
Abd Rabbih (d. 940 AD) ${ }^{98}$ and al-Aghani written by intellectual Abu al-Faraj al-Isfahani ${ }^{99}$ (d. 967 AD). These books use the language of isnad to transfer knowledge and cultural products of poets, historians and scholars in different fields of knowledge.

Warraqun (book sellers/publishers) were not able to distribute the books to the public before obtaining ijaza (approval) from the author to ensure that the book's content was created by the author himself. Usually, books started with a phrase that indicated the content of the book was heard from the author (sama'un a'nn) and copied by a specialised person known as nasikh (copier). ${ }^{100}$ In this sense, ijaza contributed to preserving the right to attribution and integrity for authors. Additionally, the concept of ijaza resembles the right to publish granted to authors in civil jurisdictions since books subject to ijaza were not communicated to the public without the approval of the author.

The concept of ijaza essentially emerged and developed in the course of reporting the texts of the Sunnah (teachings of the Prophet), where scholars of Sunnah used to grant permissions to their students to report hadīth (sayings of the Prophet). In their translation and commentary of Sahih Muslim, Nasiruddin al-Khattab and Abu Khaliyl observe that:

Ijazah was a kind of permission, oral or written, given by teacher to student authorizing him to relate some particular book or books of the teacher or his sound narrations. According to [this] system ... an expert Hadith memorizer, in order to benefit by the teacher, would present a written collection (of hadith) [plural for hadith] to him. The teacher would review and check it and, when he was sure it contained only the hadith narrated by him, would say to the student: 'I know the collection you gave me. I recognised its contents. They are my own narrations from my teachers

waldkhaer-.pdf

98 Abd Rabbih, al-Iqd al-Farid,Islamic Books (Mar, 12, 2014) http:// www.islamicbook.ws/adab/alaqd-alfrid-.pdf) 2014) http://www.islamicbook.ws/adab/alagani-011.html 
(Sheikhs). You may narrate them on my behalf.' Imam Hakim says that the hadith scholars (Muhaddith) of Al-Madinah, Makkah, Küfa, Syria, Egypt, Khorasan and other places gave this kind of permission to their students. ${ }^{101}$

The famous Fihirist of Ibn Nadim may be seen as an additional example that depicts the importance of the right to attribution in Islamic civilisation since the 900s. Ibn Nadim (d. $995 \mathrm{CE}$ ) who believed to be in charge of Bayt al-Hikma at some point of his life ${ }^{102}$ authored a comprehensive and detailed document known as Fihrist al-Ulum "The Index of the Sciences". ${ }^{103}$ The Fihrist contained accounts on thousands of authors and the books which they had authored. ${ }^{104}$ The Fihirist functioned, among other things, as a registrar for authorship by which the attribution of books for their proper authors would be verified for the next 700 years. ${ }^{105}$

Moreover, al-Suyuti (1505 CE) is a symbolic example which reflects the importance of preserving the authors' moral rights. He authored an entire book that dealt with the infringement of moral rights in books. ${ }^{106}$ His book is titled al-Fariq bayn al-Musannif wa al-Sariq (the difference between original author and the infringer).

At the introduction of his book, al-Suyuti quotes verses

$101 \quad$ Abu Tahir, above note 64 at 24.

$102 \quad$ Wellisch, above note 39 at 8.

103 Wellisch, above note 39 at 6.

104 In the introductory section of the Fihirist, Ibn Nadim summarises the content of his book. He states that: "This is a catalogue of the books of all peoples, Arab and foreign, existing in the language of the Arabs, as well as of their scripts, dealing with various sciences, with accounts of those who composed them and the categories of their authors, together with their relationships and records of their times of birth, length of life, and times of death, and also of the localities of their cities, their virtues and faults, from the beginning of the formation of each science to this our own time, which is the year three hundred and seventy-seven after the Hijrah." Bayard Dodge, The Fihrist of Al-Nadim: A Tenth-Century Survey of Muslim Culture (Columbia University Press 1970)1-2.

$105 \quad$ Wellisch, above note 39 at 11.

106 Jalal al- Dīn al-Suyuti, al-Fariq Bina al-Musanifwa al-Sariq ('alim al-Kutub, 1998). 
and Hadīth from the Qur'ān and Sunnah as well as sayings of Muslim scholars that established a religious obligation to protect the attribution and integrity of knowledge and information. In this book, he did not differentiate between religious knowledge and non-religious knowledge. ${ }^{107}$

Al-Suyuti proceeds to give a detailed account of the importance of honesty in recognising the original authorship of others by giving examples from various juristic works of Islamic scholarship and literature which show how eager the authors were in attributing the opinions they cite in their own books to the proper person. ${ }^{108}$

The main objective of al-Suyuti's book was to record the infringement of two of his books. He argues that his books were part of his personality and that he used language which is unique to his writings and spent 20 years in composing these books. ${ }^{109} \mathrm{He}$ used various expressions of condemnation to illustrate his dissatisfaction about the alleged theft $\mathrm{t}^{110}$ and indicated that infringement of books is a sin under Islamic law. ${ }^{111}$

Islamic sources did not only contribute to the emergence and development of authorship itself, they also contributed to developing some of the first traditions in relation to protecting the attribution and integrity of knowledge and cultural products. The verses of the Qur'ān and the sayings of the Prophet, as well as the mechanisms which developed as a result of their recording, clearly align with the modern objectives underpinning the protection of moral rights under international copyright treaties.

\footnotetext{
$107 \quad$ Al-Suyuti, above note 106 at 33-34.

$108 \quad$ Al-Suyuti, above note 106 at 40.

109 Al-Suyuti, above note 106 at 33-34.

$110 \quad$ Al-Suyuti, above note 106 at 33.

$111 \quad$ Al-Suyuti, above note 106 at 44.
} 


\section{CONCLUSION}

As is the case with other ancient civilisations, ${ }^{112}$ Islamic civilisation did not develop an advanced indigenous counterpart to the modern copyright systems. ${ }^{113}$ This observation includes moral rights. However, the Islamic sources and the traditions of authorship seem to recognise and promote a theory of moral rights as known in the civil law jurisdictions and as set forth in the international copyright treaties starting from the Berne convention.

Islamic sources emphasises moral and ethical principles which promote the rights of attribution and the right of integrity. Various historical examples reflect the developments of authorship in Islamic civilisation and reveal a strong commitment to notions of moral rights, particularly the rights to attribution and integrity. From this perspective, the recognition of moral rights for authors of literary and artistic works is part of the Islamic culture. Therefore, in countries with dominant Muslim populations, the protection and enforcement of moral rights are relevant to the cultural and local context even though the modern articulation of the protection of moral rights originated in the West.

Additionally, the comparative scholarship on moral rights and copyright literature in the Arab world and beyond are called to recognise the contributions of Islamic sources and traditions of authorship to the development of moral rights concepts.

$112 \quad$ This assumption applies precisely to the Chinese civilisation. See William Alford, To Steal A Book Is An Elegant Offence: Intellectual Property Law In Chinese Civilisation, (Stanford University Press, 1995), 2.

113 Compare Carla, Hess, The Rise of Intellectual Property, 700B.C.A.D. 2000 : An Idea in the Balance Daedalus: Spring, The American Academy Of Art And Science (2002) available online at http://www. amacad.org/publications/spring2002/hesse.pdf 